\title{
BILINGUAL EDUCATION AS A MEANS OF LEARNING FOREIGN LANGUAGES IN UKRAINE AND EU
}

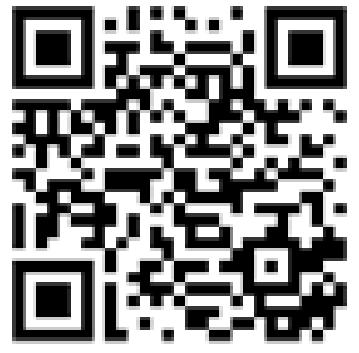

To cite this article:

\author{
Nina Nikolska, $\mathbf{P h D}$ \\ Senior Scientific Officer, \\ Comparative Education Department, \\ Institute of Pedagogy \\ National Academy of Educational Sciences of Ukraine \\ Kyiv, Ukraine \\ nina777-07@hotmail.com \\ https://orcid.org/0000-0003-3393-3248
}

\begin{abstract}
The main tasks were determined: the study of bilingual education phenomenon involved a theoretical analysis of the pedagogical domestic experience; it was carred out the essential characteristics of the basic concepts in the context of the problem under study. In the article the author considers the content of the terms "bilingual education" and "bilingual instruction". The author claims that these two concepts are often used in pedagogical sources. The analysis of these two directions and their main features is carried out, the author considers it necessary to distinguish between these two concepts: the cultures from which these two languages originated. Bilingual instruction is a process by which curricula or approaches are designed to facilitate learning for non-English-speaking students in primary and secondary schools by teaching them in their native language and in English. The author concludes that the bilingual education is a means of obtaining education using two languages as a means of teaching, in the process of which a personality is formed, open to interact with the outside world.
\end{abstract}

Keywords: bilingual education; bilingual instruction; educational programs; foreign culture; language competence; learning foreign languages; subject competence.

\section{INTRODUCTION, PROBLEM STATEMENT}

Language education is an important tool that forms the consciousness of an individual and his ability to be socially mobile in society, contributes to the dialogue of cultures in the world, which is globalizing around the various problems' solution. New realities need changes in determining the proficiency levels in foreign languages, new approaches to the content selection and organization of materials, the use of adequate forms and types of control. In the Communiqué "Strengthening European Identity through Education and Culture", the European Commission sets out a vision for an educational space where high-quality education is not limited to staying in another country. It is important to know two more languages, besides the native one. This facilitates employment and education in the EU countries. People develop a sense of their identity as Europeans, as well as an understanding of the shared culture, linguistic heritage of Europe and its diversity. 
The purpose of the paper is to review the concept of bilingual education of schoolchildren and clarify the bilingual education organisation in Ukraine and EU. According to the goal, the main tasks of the paper are: the study of the phenomenon of bilingual education involving a theoretical analysis of the national pedagogical experience; to carry out the essential characteristics of the basic concept of the bilingual education.

\section{LITERATURE REVIEW}

The analysis of pedagogical literature, namely the studies of S. Krashen, D. Saer, N. Hornberger, J. Fishman, C. Baker, J. MacNamara, J. Cummins, B. Spolsky, indicates that bilingual education is in the center of attention of many researchers. They believe that this type of school education is quite successful, which necessitates of foreign languages further studying. The analysis of the Ukrainian pedagogical literature, namely the studies of I. Biletska (Biletska, 2013), T. Bodnarchuk (Bodnarchuk, 2012), T. Burda (Burda, 2001), O. Demianenko (Demianenko, 2004), N. Zaitseva (Zaitseva, 2014), O. Kuznetsova (Kuznetsova, 2002), O. Milyutina (Milyutina, 2008), N. Nikolska (Nikolska, 2019), L. Tovchigrechka (Tovchyhrechka, 2012), indicates that bilingual education is a topical research problem in Ukraine. To comprehend the problem of bilingualism and bilingual education, the works of Ukrainian comparativists are important, who highlight the general trends in the development of education in Europe and the world focusing on priority innovations, in particular key competencies in education (A. Dzhurylo et al., 2016; O. Maksymenko, 2015; Lokshyna, 2019).

\section{METHODOLOGY}

This is a theoretical study. The authentic sources of C. Baker (2008) (1996) a, S. Krashen, D. Saer, N. Hornberger (1996) a, J. Fishman (1996) were analysed. To solve the designated tasks and achieve the goal, the following methods were used, i.e. analysis, synthesis, comparison, generalization (for studying and generalizing scientific literature on the specific scientific methodology of the problem, conducting a categorical analysis of basic concepts and designating the relationship between them).

\section{MAIN RESULTS}

The diversity is at the heart of Europe's cultural wealth. It is a common European heritage and the basis for the unification of Europe, as the Council of Europe Cultural Program aims to promote:

- awareness and development of the multifaceted European cultural heritage;

- search for answers to the problematic questions facing the European society today, such as globalization and its impact on the cultural policies of the member states of the Council of Europe.

To find ways to solve these problems in a mosaic European society, the multicultural education is called upon. An important socio-political determinant of multicultural education is the intensive development of integration processes as an important component of the modern world, as well as the desire of countries to integrate into the world and European socio-cultural space, while maintaining national uniqueness.

Certain aspects of school bilingual education are considered by the English scientist Stephen D. Krashen, who in his study "The goals of bilingual education and their importance" (2003) described the process of teaching a non-native language, identifying three main elements in the content of bilingual programs: teaching a subject in the native language 
without translation, developing literacy in the first language and thoroughly learning English as an auxiliary (Baker, 2008).

The English researcher David Saer, in “The Bilingual Problem” (2008), suggested that bilingual schoolchildren in Wales experience a decline in IQ due to bilingualism. He defined bilingual education as an interconnected activity of a teacher and students in the process of studying individual subjects in their native or foreign languages, as a result of which a synthesis of a certain competence is achieved, which ensures a high level of proficiency in a foreign language and the subject content assimilation (Gonzales, 2008).

Professor and Director of the Educational Linguistics Program at the University of Pennsylvania, Nancy Hornberger, Editor-in-Chief of the ten-volume Encyclopedia of Language and Education, Leading Specialist on Bilingual Education, Language Policy, language law at the national and international levels, in her scientific works has provided guidance for schools and educators in order to better understand the complex nature of bilingualism, bilingual education and language policy in multilingual societies (Gonzales, 2008). She developed a typology of bilingual education, dividing it into models of bilingual education and varieties of programs for bilingual education, where the models include whole language planning and ideological orientations between linguistic and cultural differences in society. She described the varieties of programs for bilingual education as having specific context and structural characteristics. At the same time, models are viewed as abstract categories that help us understand, at a general level, a bilingual curriculum. So, N. Hornberger offered us the following structure of three main models of billingual education (Gonzales, 2008) (Table 1).

Table 1

The structure of the main models of bilingual education (by N. Hornberger)

\begin{tabular}{|l|l|l|}
\hline \multicolumn{1}{|c|}{ Transitional model } & \multicolumn{1}{c|}{ Maintenance model } & \multicolumn{1}{c|}{ Enrichment model } \\
\hline $\begin{array}{l}\text { Language shift } \\
\text { Cultural assimilation } \\
\text { Social incorporation }\end{array}$ & $\begin{array}{l}\text { Language maintenance } \\
\text { Strengthened cultural identity } \\
\text { Civil rights affirmation }\end{array}$ & $\begin{array}{l}\text { Language development } \\
\text { Cultural pluralism } \\
\text { Social autonomy }\end{array}$ \\
\hline
\end{tabular}

1. The transitional model unites all those bilingual education programs that are aimed at the transition to the language of the majority for children of the linguistic minority for further assimilation in the general cultural flow and becoming a member of society. The transitional model of bilingual education uses the first language (L1) of minority students in primary education, but the goal is to shift students' minds away from using the first language as quickly as possible and push them to use a predominant, adaptive language to the mainstream language of general education. In most transitional programs, the first language is used for one to two years, then it is replaced by the second language. Hence, this model is seen as a subtractive and weak bilingual model

2. The maintenance model includes all bilingual learning models that support minority language learners in order to preserve their mother tongue, strengthen their cultural identity and validate their social rights in society. The supportive model is fundamentally different from the transitional approach in bilingual education; its goal is to support the minority language, enhance cultural and linguistic identity and affirm their individual and collective ethnolinguistic rights. The maintenance bilingual model includes later programs using the first language (L1) as the language of instruction, which lasts four years. This model is an additive and strong bilingual model; it is used in Wales (UK), Catalonia (Spain) and French Canadians in Canada. 
3. The enrichment model supports all bilingual education programs that stimulate the development of minority languages at the individual and collective levels, as well as pluralism at school and in the community, and integrate the national community based on the autonomy of cultural groups.

Closely related to bilingual maintenance programs are enrichment programs. This term was first proposed by J. Fishman in 1976. While the previous models are aimed to support the first language of minority students, this model is mainly associated with the study of the majority language through the (target) main language of the minority. Examples of enriching models for bilingual education are French immersion in Canada, where many (middle-class, English-speaking students) are learning French. This is one of the most successful examples of enriching bilingual programs. Another example is Welsh high schools, which also have many middle-class people who are learning English. Elite bilingual programs using the European Schools movement can also be classified as enriching programs (Fishman, García, 2010).

The model of bilingual heritage language teaching is mainly associated with the revitalization of the local language through a wide range of educational initiatives for the local language revitalization. This group also includes immigrants. Such programs have similarities with additive (strong bilingual approach). Typically, this model is a cross between supporting and enriching models in terms of the status of the first (L1) and second (L2) languages of learners. The last level where we can explore bilingual / immersion education is the program level. As Hornberger argues, bilingual programs have more specific categorization than models, and can differ from each other by analyzing specific contextual and structural characteristics. Contextual characteristics include descriptions of the student body (number, stability, school mobility, minority status, language basis) and teaching staff (ethnicity, level of bilingualism, training, responsibilities). Structural characteristics include "school curriculum", "linguistic meaning" (level of coherent speech development, coordination, oral / literary development, subject placement of languages) and "use of language in the classroom" (Gonzales, 2008).

The British scientist, professor at the University of Bangor (Wales) C. Baker is the author of fundamental works in the field of bilingual education and bilingualism, in which he revealed the peculiarities of bilingual education in UK schools: "Aspects of Bilingualism in Wales", "Bilingualism in Wales" (2005), "Key Issues in Bilingualism and Bilingual Education" (2008). He introduced a comprehensive plan to apply the language and expand the theory of language planning, which was to reproduce the language in the family, preschool education and schools through bilingual education. In addition to his active scientific work and indisputable academic influence, $\mathrm{K}$. Baker participated in the formation and implementation of the language policy of Wales. From 1997 to 2007, he was appointed as a government expert responsible for the preservation of the Welsh language in Wales. In 2007, K. Baker, M. Deuchar, D. Gathercole created a prestigious international interdisciplinary research center at the University of Bangor Bilingualism in theory and practice (Bilingualismin Theory and Practice) which consisted in the development of new directions studies of bilingual education, its structure, practical application methods by students and society as a whole (Gonzales, 2008).

The Irish researcher John MacNamara in "Bilingualism and Primary Education. Exploring the Irish Experience" (2006) examined the results of teaching mathematics in Irish to Englishspeaking students and described the quality of the Irish language revitalization program in national schools relative to English. His study involved 119 schools with 1,084 students who were asked to solve math tests in Irish and English to check their IQ. The result showed that children for whom English is their native language, and they are taught in Irish, are 11 months behind students who study mathematics in their native language, although their level of knowledge in mathematics is high. The scientist insisted that bilingual education is not only ineffective, but on the contrary negatively affects the study of the main language (Baker, 2008). 
The Irish scholar Jim Cummins, who denied John McNamara's claim that bilingual education is ineffective. The scientist believed that before testing the mathematical knowledge of students, they should test their knowledge of the language. To prove his opinion, J. Cummins compared the knowledge of students from three Irish and two English schools in Dublin. Students' reading technique was tested and the result was positive. This proved that bilingual education does not affect the development of the majority language. The most famous works of J. Cummins: "Bilingualism and Special Education: Issues in Assessment and Pedagogy", "Language, Power and Pedagogy: Bilingual Children under the Crossfire" (Language, Power and Pedagogy: Bilingual Children in the Crossfire) (Baker, Hornberger, 1996).

J. Cummins played an important role in preserving the culture and language of the Ukrainians in Canada. The persistent enthusiasm of the Ukrainian community contributed to the writing of the work "Focus on Ukrainian-English bilinguals" (1995). At the University of Albert, the Association of Ukrainian Bilingual Education was revived, the purpose of which was to strive to save the language from absorbing it into Russian, to preserve, develop and constantly apply it in everyday life. Such a powerful social position of Ukrainian emigrants and the scientific base led to the fact that the Ukrainians of Canada speak their native language at a fairly high level, this fact proves the bilingual education effectiveness (Baker, Hornberger, 1996).

The Irish researcher John Harris in the research study "Conversational Irish in Primary School. Analysis and Achievement" (2004) examined the quality of students' knowledge of the Irish language when applying bilingual instruction. He has proven that teaching in immersion schools helps students develop minority language communication skills compared to those who study Irish only 5 hours a week in English schools. So, J. Haris highlighted the positive aspects of immersion education, which contributed to the development and increase in the number of such schools in Northern Ireland (Baker, 2008).

Bilingual education in Scotland is less researched than in other parts of Britain, but it has also been studied by scholars such as M. Stephens Linguistic Minorities in Western Europe (1996), N. Grant in Cultural diversity and Education in Scotland (1994), C. Withers "Gaelic in Scotland 1698-1981" (Gaelic in Scotland 1698-1981) (1999), K. MacKinnon Scottish Opinion on Gaelic (2002) (Baker, 2008).

The scholar Joshua Fischman, in his "Bilingual Education: An International Sociological Perspective” (1992), "Bilingual Education: Contemporary Perspectives" (1992), proposed four principles of the bilingual education:

1. Bilingual education is beneficial for the majority group.

2. Bilingual education is beneficial for the minority group.

3. Bilingual education has a positive impact on education.

4. Bilingual education is effective for language learning and language teaching.

So, J. Fishman believes that bilingual education is useful for many reasons: it presupposes loyalty and integration into society; does not allow languages to predominate or dominate, but on the contrary, leads to mutual understanding and fair, equitable use; expands the economic, social and cultural opportunities of the bilingual. The author highlights the bilingual education typology, which is based on the sociolinguistic aspect of the language, namely:

Type 1 - Transitional Bilingual Education: bilingualism leading to the displacement of the native language;

Type 2 - Monoliterate Bilingual Education: bilingualism aimed at mastering the writing of a second language; literacy skills develop only in the dominant language;

Type 3 - Partial Bilingual EducatIon: partial bilingualism, when the humanities are taught in two languages, and the natural sciences are taught in the state dominant in the country of study; 
Type 4 - Biliterate Bilingual Education: full bilingualism - equality of study of two languages, when, thanks to training, the original language and culture is preserved and at the same time masters the language that is official in the country of study (Fishman, Garcia, 1996).

Another leading expert in bilingual education, Ofelia Garcia, in her research papers Bilingual education (2004), Handbook of Language and Ethnic Identity (with J. Fish), analyzed bilingual education history and policy, and also disclosed the goals and types of bilingual education (Fishman, Garcia, 1996).

Linguist Bernard Spolsky has developed the Education evaluation model for bilingual education, which aims to provide a comprehensive validation of all aspects of such learning. The model is described as a tiered wedding cake, where each level has the same important part - all those aspects that affect bilingual education: psychological, sociological, economic, political, religious, cultural, geographic, demographic, historical and linguistic. The imaginary cake has four levels; at the center is education. The first level is the general situation of the community in which bilingual education is functioning. The community can be ethnic group (Asians), country (Wales), locality (St. Lambert). This level assumes that bilingual education always presupposes broad social, cultural, political and economic discussion. The second level involves the bilingual education programs implementation. Program proposals are made by the government, local institutions, parents, communities. On the basis of these proposals, a "hidden" program is made, which is consistent with the main goal: avoiding misunderstandings in teaching. The third level is the operation and testing of bilingual classes and schools. The fourth level assumes the bilingual education result: linguistic skill, knowledge of cultures, selfesteem, professional success, a positive attitude towards two languages (Spolsky, 1999).

Summarizing, we note that bilingual education in Europe and the world today is developing against the background of traditional methods criticism of learning foreign language, which do not fully meet the modern society needs, since they do not provide full preparation of students for future professional activities, do not use the possibilities of interdisciplinary connections. Teaching with the use of two languages as a means of obtaining education basically has bilingual educational programs in various academic disciplines, which in fact represent an alternative way of mastering the subject content of academic disciplines by means of native and foreign languages, aimed at achieving by students a synthesis of linguistic, subject and intercultural competence. So, from the point of view of the implementation of the pluralism ideas and multicultural education, bilingual education in European countries most fully meets expectations. Its goal is integration into the modern European and world space, intercultural communication and multicultural education.

Billingual education is an important component of the modern system of general secondary education in the UK, which leads her research. A feature of bilingual education in Britain is the integrated learning content, which requires the teacher to use different examples from different cultures in describing the basic educational concept of learning, which is effective for students with different cultural identities. The goal is to achieve the highest levels of tolerance, strengthening school and social structures that are created for students and teachers to cross racial and ethnic boundaries.

The British scientists also note such essential characteristics of bilingual school education as the importance of the language planning goals; structuring the content of bilingual educational programs in various academic disciplines, which in fact represent an alternative way of mastering the subject content of academic disciplines by means of native and foreign languages and are aimed at achieving by students a synthesis of linguistic, subject and intercultural competence; subject placement of languages (humanitarian disciplines are taught in two languages, and natural disciplines are taught in the official, dominant in the country of study); equality of two languages study, when, thanks to training, the original language and 
culture is preserved and at the same time masters the language that is official in the country of study; strengthening students' cultural identity and confirming their rights in society; expanding the economic, social and cultural opportunities of the bilingual.

Based on this, let us find out the content of the term "bilingual education". In pedagogical sources, the terms "bilingual education" and "bilingual instruction" are often used side by side, traditionally considering education as a process. We consider it necessary to distinguish between these two concepts: Bilingual education (bilingual, bicultural education - bicultural education) is a process, the implementation of which takes place on the basis of the use of two programs in order to master the content of subjects that include the cultures from which these two languages originated. (Harlow, 2008). Bilingual instruction is a process by which curricula or approaches are designed to facilitate learning for non-English speaking students in primary and secondary schools by teaching them in their native language and in English (Harlow, 2008). Billingual education is a means of obtaining education using two languages as a means of teaching, in the process of which a personality is formed, open to interact with the outside world. The ones used for this language are: one is the mother tongue, and the other can be the second mother tongue if the student is a representative of natural (everyday) bilingualism; or in a foreign language (non-native, foreign). Languages can have different status in society: state, official foreign, language of a national minority or regional language. Since in the process of bilingual education a non-native or foreign language is considered not only as a means of everyday communication, but also as a tool for learning the world of special knowledge, as a result, students achieve a high integrative level of linguistic and subject competence.

The billingual education is an effective way of development not only for national minorities, but also for every citizen of Ukraine, which accelerates the integration process both in the domestic society and in Europe, and harmonizes relations between people speaking different languages. Bilingual education on the principle of Ukrainian + foreign is acquiring particular relevance in the light of the common European polymotic trends, the integration of our state into the European educational space, the spread of student exchange practice and the educational system openness of our country for foreign students.

The dissemination of the foreign languages study fits into the context of the European directives, which recommend that the Member States teach in educational institutions, in addition to the state language, two more languages of the European Union. Bilingual education in Ukraine is an adequate answer to the issues of linguistic and cultural diversification in Europe.

\section{CONLUSIONS}

The bilingual education analysis of schoolchildren and the bilingual education in Ukraine and EU was conducted in the several aspects, i.e. the study of bilingual education phenomenon based on the theoretical analysis of the pedagogical domestic experience; the study of the essential characteristics of the basic concepts of the bilingual education.

Bilingual education is quite common phenomena in the European countries. As a rule, such training does not need artificial encouragement, since it helps to expand the general educational horizons of students through familiarization with the peculiarities of a foreign language culture, the formation of a tolerant attitude towards the views, cultural characteristics of representatives of another culture associated with national specifics. This process stimulates the need for further self-education and self-development, which is a necessary condition for professional activity in the modern world. The EU encourages the Member States to take further action in the field of education with a view to improving the acquisition of basic skills, in particular to learn at least two foreign languages from an early age. The use of innovative 
methods of teaching foreign languages in secondary school will allow achieving higher success in obtaining basic knowledge by students, in particular in mastering foreign languages.

\section{REFERENCES}

Baker, C. (2008). Key Issues in Bilingualism and Bilingual Education. Multilingual Matters Limited.

Baker, C., Hornberger, N. (1996). An Introductory Reader to the Writings of Jim Cummins. Multilingual Matters LTD.

Biletska, I. O. (2013) Inshomovna osvita u serednikh navchalnykh zakladakh SShA:polikulturnyi kontekst [Candidate's thesis]. Uman.

Bodnarchuk, T. (2012). Rozvytok bilinhvalnoi osvity v Avstrii (1945-2010 rr.) [Candidate's thesis]. Lviv.

Burda, T. M. (2001). Movna povedinka osobystosti v umovakh ukrainsko-rosiiskoho bilinhvizmu. [Candidate's thesis]. Kyiv.

Council of Europe. (2020). Common European Framework of Reference for Languages: Learning, Teaching, Assessment - Companion volume. Council of Europe Publishing. https://rm.coe.int/common-european-framework-of-reference-for-languages-learningteaching/16809ea0d4

Demianenko, O. Ye. (2004). Formuvannia slukho-vymovnykh navychok u shestylitnikh uchniv $u$ sytuatsii bahatomovnosti [Candidate's thesis]. Zaporizhzhia.

Dzhurylo, A. P., Hlushko, O. Z., \& Lokshyna, O. I., Mariuts, I. O., Tymenko, M. M., and Shparyk, O. M. (2018). Transformatsiini protsesy u shkilnii osviti krain Yevropeiskoho Soiuzu ta SShA: monohrafia. TOV «KONVI PRINT». https://core.ac.uk/download/pdf/163088295.pdf

Dzhurylo, A. P., Mariuts, I. O., \& Shparyk, O. M. (2016). Pro navchannia anhliiskoi movy v krainakh YeS. Ukrainskyi Pedahohichnyi Zhurnal, 1, 6-15.

http://uej.undip.org.ua/upload/iblock/d03/d033eff40517cc1645fd0b1d251c48b3.pdf

European Commission. (2003). Promoting Language Learning and Linguistic Diversity: An Action Plan 2004 - 2006. https://eur-lex.europa.eu/LexUriServ/LexUriServ.do?uri=COM :2003:0449:FIN:en:PDF

Fishman, A., Garcia, O. (1996). Handbook of Sociolinguistics. Blackwell Publishers.

Fishman, A., García, O. (2010). Handbookof language and ethnic identity. Oxford University Pres.

Gonzales, J. (2008). Encyclopedia of Bilingual Education. A SAGE Reference Publication.

Harlow, G. U. (2008). Bilingual Education for Minorities. Encyclopedia of Language and Education (2nd Edition, Vol. 3, pp. 123-125). Springer, Kuznetsova, O. Yu. (2002). Rozvytok movnoi osvity u serednikh I navchalnykh zakladakh Velykoi Brytanii druhoi polovyny XXst. [Doctor's thesis]. Kharkiv.

Lokshyna, O. (2019). Stratehichni oriientyry mizhnarodnykh orhanizatsii u haluzi osvity. Ukrainskyi Pedahohichnyi Zhurnal, 2, 5-14. https://doi.org/10.32405/2411-1317-2019-2-5-14

Maksymenko, O. (2015). Orhanizatsiia ta zmist navchannia suchasnykh inozemnykh mov u lantsi serednoi osvity Velykoi Brytanii. Naukovi Zapysky. Seriia: Pedahohichni Nauky, 135, 161-166. https://www.cuspu.edu.ua/images/download-files/naukovi-zapysky/v135.pdf

Miliutina, O. K. (2008). Polikulturna osvita shkoliariv u Velykii Brytanii. Vydavnytstvo ZhDU im. I. Franka.

Nikolska, N. (2019). Bilinhvalna osvita shkoliariv yak predmet doslidzhennia vitchyznianykh uchenykh. Pedahohichnyi Dyskurs, 26, 14-18. https://doi.org/10.31475/ped.dys.2019.26.02

Ruda (2007). Komunikatyvni deviatsii v umovakh ukrainsko-rosiiskoho bilinhvizmu [Candidate's thesis]. Kyiv. 
Spolsky, B. (1999). Concise Encyclopedia of Educational Linguistics. Pergamon Elsevier University of Edinburg, Science Ltd Copyright.

Topuzov, O. M. (2015). Zabezpechennia yakosti zahalnoi serednoi osvity: na shliakhu do yevropeiskykh standartiv [The guarantee of the quality of the comprehensive secondary education: on the way to the European standards]. Ukrainskyi pedahohichnyi zhurnal, $1,16-27$.

Tovchyhrechka, L.V.(2012). Dvomovnaosvitavuniversytetakh SSHA (kinetsXXpochatokXXIst.) [Candidate's thesis]. Sumy.

Zablotska, L. M. (2010). Dydaktychni osnovy movnoi pidhotovky uchniv u pochatkovykh skolakh Velykoi Brytanii v gruhii polovyni XX - na pochatku XXI st. [Candidate's thesis]. IvanoFrankivsk.

Zaitseva, N (2014). Teoretychni zasady rozvytku dvomovnoho navchannia v multykultyrnomu seredovytshi SShA. Porivnialno-pedahohichni stydii 6(20), 45-52. https://library.udpu. org.ua/library_files/poriv_ped_stydii/2014/2014_6/7.pdf 